\title{
HARVEST OF ENDANGERED MARINE INVERTEBRATES IN A PRIORITY AREA FOR CONSERVATION IN BRAZIL
}

\author{
Flavia C. F. Pinheiro, ${ }^{1,2}$, Hudson T. Pinheiro ${ }^{1,3,4, *}$, Thiago J. F. Costa ${ }^{1}$, \\ João B. Teixeira ${ }^{1,5}$, João L. Gasparini ${ }^{2}$, Jean-Christophe Joyeux ${ }^{2}$, Agnaldo S. Martins ${ }^{2}$ \\ ${ }^{1}$ Associação Ambiental Voz da Natureza, Brazil \\ ${ }^{2}$ Federal University of Espirito Santo, Brazil \\ ${ }^{3}$ University of California Santa Cruz, USA \\ ${ }^{4}$ California Academy of Sciences, USA \\ ${ }^{5}$ State University of Santa Cruz, Brazil \\ *e-mail:htpinheiro@gmail.com
}

Received: 10.03.2017

\begin{abstract}
The harvesting of marine organisms for aquarium and ornamental art crafts is a very common and widespread activity, threatening a number of coral reef species. The goal of this manuscript is to report the intensive harvesting of two marine invertebrate species, the starfish Oreaster reticulatus and the gorgonian Phyllogorgia dilatata, in reef environments of a national priority area for the creation of a Marine Protected Area (MPA) in the Espírito Santo State, central coast of Brazil. These species were present on the 2003 Brazilian Red List of Endangered species as threatened of extinction, but $P$. dilatata was removed from the most recent 2014 Brazilian Red List, while $O$. reticulatus is currently considered vulnerable. Neither species have been assessed by IUCN. The harvest of these invertebrates was registered in $17 \%$ of the 51 days of monitoring (ten expeditions between March 2005 and February 2006), with catches of up to 24 starfishes and 1000 gorgonians in a single day. Starfishes used to be sold to local traders for US\$ 0.50 each, and each gorgonian for US\$ 0.15 . This starfish is already in decline on a regional scale, and the actual harvesting rate of the gorgonian could lead to the extinction of the local population in about 17 years of exploitation. Due to the ecological importance of these two endangered species, their harvest threatens the entire local rocky reef ecosystem. Further ecological and fisheries studies on these species should be conducted, and the definition and creation of the MPA could help to manage all the unsustainable activities conducted and expected in the region.
\end{abstract}

Key words: endangered marine invertebrates, gorgonian, harvest, Marine Protected Area, Oreaster reticulatus, Phyllogorgia dilatata, starfish

The harvesting of marine organisms for aquarium and ornamental art crafts is a very common and worldly widespread activity (Sadovy \& Vincent, 2002; Rhyne et al., 2012). However, this practice has been shown to be a threat of very high potential (Lecchini et al., 2006), and, consequently, many harvested species are endangered and under risk of extinction (Gasparini et al., 2005). In Brazil, the activity uses about 120 marine fish and 65 invertebrate species (Gasparini et al., 2005), including eight vulnerable fishes and five vulnerable and endangered invertebrates species (MMA, 2014). Although threatened species have been protected under Brazilian law, few efforts toward the education and conservation awareness have been applied to the coastal communities and tourists, that are, respectively, the main harvesters and consumers of the resource. This scenario is worrisome considering that it has happened without control in areas of high-priority for marine conservation. Since these priority areas still have natural attributes preserved, they have been visited more by both harvesters and tourists (Pin- heiro et al., 2009). Moreover, both activities are intertwined, where harvesters and coastal communities commonly incentive tourists to fish and collect organisms, and tourists fund the activity buying the harvest.

This study has the goal to report and estimate the impact of intensive harvesting of two key marine invertebrate species, the starfish Oreaster reticulatus (Linnaeus 1758) and the Brazilian endemic gorgonian Phyllogorgia dilatata (Esper 1806), in the Franceses Island, Espírito Santo State, Brazil (Fig. $1,2)$. Both species were present in the 2003 Brazilian Red List of Endangered species, considered threatened of extinction (Machado et al., 2008). The most recent 2014 Brazilian Red List (MMA, 2014) followed IUCN workflow and classifications. This resulted in $P$. dilatata not been included and $O$. reticulatus to be considered vulnerable. Both species remain not assessed by IUCN. During one year of monitoring (51 field days between March 2005 and February 2006), recreational and commercial fishing activities performed in the Franceses Island sur- 
rounding waters (up to $300 \mathrm{~m}$ radius, a total of 500 $000 \mathrm{~m}^{2}$ ) were recorded during the day (see details in Pinheiro et al., 2010a). The harvest of gorgonians was registered in four $(7.84 \%)$ of the monitored days, while starfish harvesting in five days $(9.80 \%)$ (Fig. 2). Through interviews conducted at the Franceses Island, two fishermen described the goal of collecting 1000 gorgonians per day, which were sold for US\$ 0.15 the unit in 2009. On the other hand, monitored catches of starfishes summed up to 24 individuals per day, which were sold 2009-US\$ 0.50 each. Both invertebrate species were sold to local traders, aiming to ornamental art craft.

Gorgonians Phyllogorgia dilatata are found in the high exposure zones of the island (about 100 $000 \mathrm{~m}^{2}, 62 \%$ of the reef habitat area), at a density of 5 individuals per $\mathrm{m}^{2}$ and normally attached on flat rocky surface (Costa, 2009; for methods and additional information about gorgonians density and mapping, see supplementary data I). This species brings a high structural complexity to the rocky reef habitat, a factor that contributes to increase the local fish diversity of the island (Pinheiro et al., 2013) and recruitment of fishes (Gasparini et al., 2005). The damage of one harvest day could reach $170 \mathrm{~m}^{2}$ of rocky reef area. Growth studies show that gorgonians experience a slow growth rate $(2 \mathrm{~cm}$ per year in average; Yoshioka \& Yoshioka, 1991), indicating that the harvested gorgonians were about 10 to 30 years old. A recent research shows that areas under intensive harvest are prone to exhibit long-term suppression of recruitment and declining populations (Lasker, 2013). Phyllogorgia dilatata is already in decline on other Brazilian reefs, with remaining populations strongly affected by tissue loss (Krohling et al., 2010; Cassola et al., 2016). In Franceses Island, the reported harvesting rate (up to 28800 individuals per year), if not controlled, could vanish the species, and consequently the entire habitat, in approximately 17 years of exploitation.

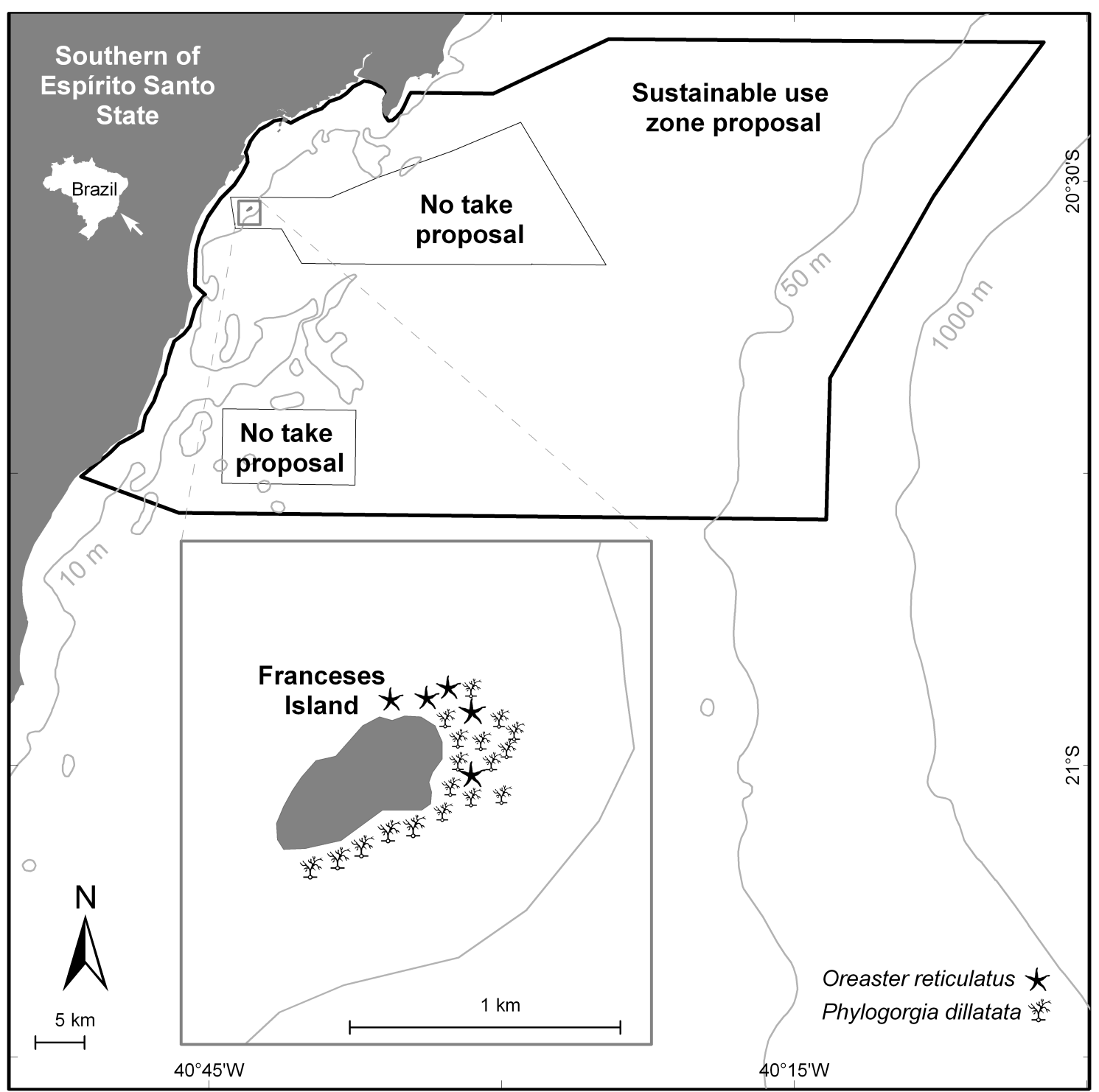

Fig. 1. Franceses Island, situated inside a marine conservation priority area in Southeastern Brazil, South Atlantic. 

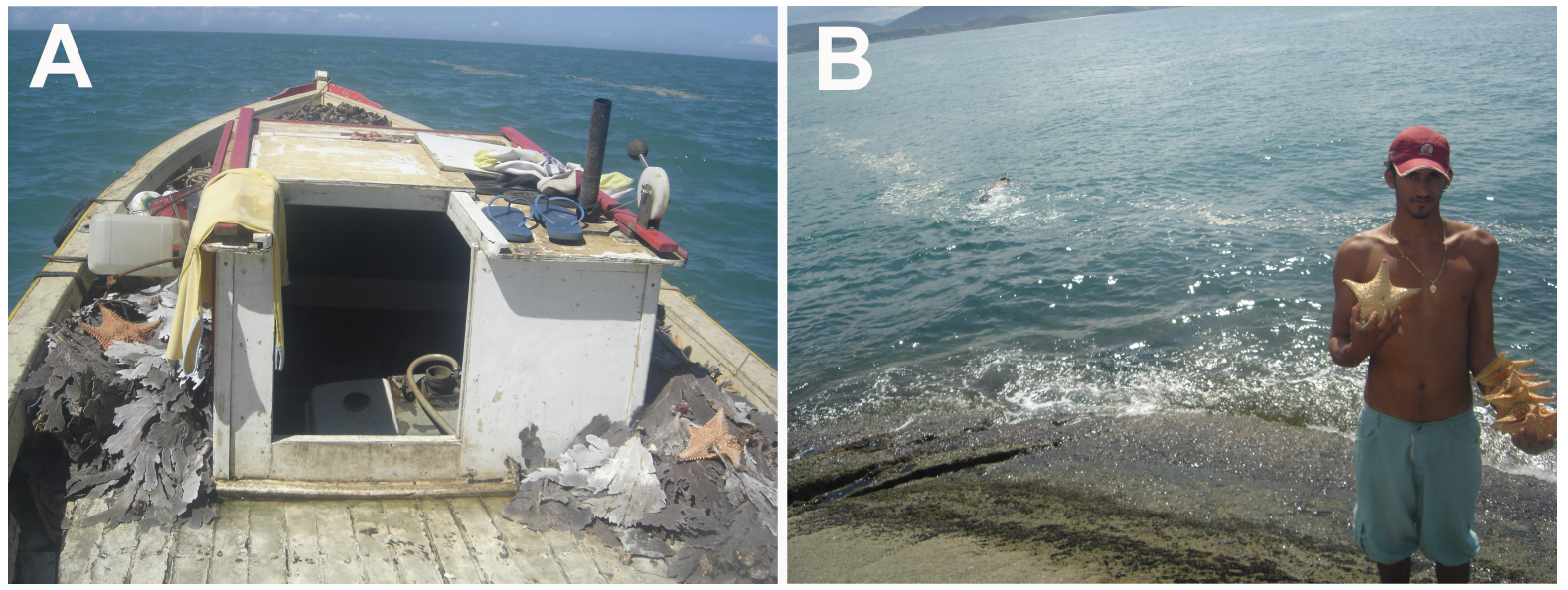

Fig. 2. Harvest activity of the gorgonian Phyllogorgia dilatata (A) and starfish Oreaster reticulatus (A, B) in a conservation priority area in the Southeastern Brazil, South Atlantic.

The starfish Oreaster reticulatus is an omnivore species, being categorised both as microphagous substratum grazer and macrophagous predator or scavenger (Scheibling, 2013). On Franceses Island, this starfish is a common predator of sponges and sea urchin Echinometra lucunter (Linnaeus 1758), both very abundant around the island (Costa 2009). It is also a prey for bigger and rarer marine invertebrates, as the gastropod Charonia variegata (Lamarck 1816). However, the species has been a common target in the Espírito Santo state for many years, with population sizes apparently declining in most of places. Recent studies indicated that $O$. reticulatus might be threatened throughout the Caribbean as well, where illegal harvesting has been also reported from Panama and unregulated extraction has occurred in many countries such as Mexico, Jamaica and Venezuela, among other countries (Micael et al., 2009; Alvarado, 2011).

Both species play an important ecological role in the local reef system and, therefore, the harvest of these two key species threatens both their populations and also the whole rocky reef ecosystem. Franceses Island is situated in a national priority area for conservation (area MaZc322, Ilhas Piúma/Francês, in MMA, 2007), and a proposal for the creation of an MPA exists since 2003. Although many biological and socio-economic studies have already been developed to design the MPA (details in Pinheiro et al., 2009, 2010b; Fig. 1), it has not been established yet. Moreover, intensive harvest of mussels, anchor damage, signs of overfishing and the expectation of port activities inside this conservation priority area are also threatening the recovery and ecological role of the reef ecosystem (Pinheiro et al., 2010a,b).

Further ecological and fisheries studies on these species should be conducted to determine the current status of the populations and evaluate the importance and environmental effects of harvesting. Consider- ing the possibility of population decline, these species should also be assessed by the IUCN, in order to establish international awareness. Franceses Island is situated in a transitional zone between tropical and subtropical realms, harbouring 221 fish species (over $30 \%$ of the Brazilian reef fish biodiversity), and considered a nursery area for many endangered species (Pinheiro et al., 2015). The creation of the MPA has now been scheduled for 15 years and its definition and establishment could help to manage the unsustainable activities conducted and expected in the region.

\section{References}

Alvarado J.J. 2011. Echinoderm diversity in the Caribbean Sea. Marine Biodiversity 41(2): 261-285. DOI: 10.1007/s12526-010-0053-0

Cassola G.E., Pacheco M.S.C., Barbosa M.C., Hansen D.M., Ferreira C.E.L. 2016. Decline in abundance and health state of an Atlantic subtropical gorgonian population. Marine Pollution Bulletin 104(1-2): 329-334. DOI: 10.1016/j.marpolbul.2016.01.022

Costa T.J.F. 2009. Estrutura da comunidade bentônica dos recifes rochosos da Ilha dos Franceses, sudeste do Brasil, utilizando a técnica amostral de fotoquadrate digital. Vitória (ES): Department of Biology FAESA. 59 p.

Gasparini J.L., Floeter S.R., Ferreira C.E.L., Sazima I. 2005. Marine ornamental trade in Brazil. Biodiversity and Conservation 14(12): 2883-2899. DOI: 10.1007/s10531-004-0222-1

Krohling W., Netto R.F., Mercier A.L.F. 2010. Estudo populacional das colônias de Phyllogorgia dilatata (Esper, 1806) em dois ambientes costeiros no Estado do Espírito Santo. Natureza on line 8(3): 123-126.

Lasker H.R. 2013. Recruitment and resilience of a harvested Caribbean octocoral. PloS ONE 8(9): e74587. DOI: 10.1371/journal.pone.0074587

Lecchini D., Polti S., Nakamura Y., Mosconi P., Tsuchiya M., Remoissenet G., Planes S. 2006. New perspectives on aquarium fish trade. Fisheries Science 72: 40-47. DOI: 10.1111/j.1444-2906.2006.01114.x

Machado A.B.M., Drummond G.M., Paglia A.P. 2008. Livro Vermelho da Fauna Brasileira Ameaçada de Extinção. Vol. 2. Brasilia: Ministério do Meio Ambiente. 1420 p. 
Micael J., Alves M.J., Costa A.C., Jones M.B. 2009. Exploitation and Conservation of Echinoderms. Oceanography and Marine Biology: An Annual Review 47: 191-208.

MMA. 2007. Áreas prioritárias para conservação no Brasil. Available from http://www.mma.gov.br/biodiversidade/ projetos-sobre-a-biodiveridade/projeto-de-conservação-e-utilização-sustentável-da-diversidade-biológicabrasileira-probio-i/áreas-prioritárias.

MMA. 2014. Portarias Nos. 443, 444, 445, de 17 de Dezembro de 2014, Diário Oficial da União. Seção 1, 245, 110 (18 December 2014).

Pinheiro H.T., Ferreira A.L., Molina R.P., Protti L.M.C., Zanardo S.C., Joyeux J.-C., Doxsey J.R. 2009. Profile of social actors as a tool for the definition of marine protected areas: the case of the Ilha dos Franceses, southern coast of Espírito Santo, Brazil. Natureza \& Conservação 7(1): 181-194.

Pinheiro H.T., Joyeux J.-C., Martins A.S. 2010a. Reef Fisheries and Underwater Surveys Indicate Overfishing of a Brazilian Coastal Island. Natureza \& Conservação 8(2): 151-159. DOI: 10.4322/natcon.00802008

Pinheiro H.T., Ferreira A.L., Teixeira J.B. 2010b. Diagnóstico ambiental do litoral sul do estado do Espírito Santo: estudos complementares para a criação de uma unidade de conservação marinha. Vitória: Associação Ambiental Voz da Natureza. 228 p.
Pinheiro H.T., Martins A.S., Joyeux J.-C. 2013. The importance of small-scale environment factors to community structure patterns of tropical rocky reef fish. Journal of the Marine Biological Association of the United Kingdom 93(5): 1175-1185. DOI: 10.1017/ S0025315412001749

Pinheiro H.T., Madureira J., Joyeux J.-C., Martins A. 2015. Fish diversity of a southwestern Atlantic coastal island: aspects of distribution and conservation in a marine zoogeographical boundary. Check List 11(2): 1615. DOI: 10.15560/11.2.1615

Rhyne A.L., Tlusty M.F., Schofield P.J., Kaufman L., Morris J.A., Bruckner A.W. 2012. Revealing the Appetite of the Marine Aquarium Fish Trade: The Volume and Biodiversity of Fish Imported into the United States. PloS ONE 7(5): e35808. DOI: 10.1371/journal.pone.0035808

Sadovy Y.J., Vincent A.C.J. 2002. Ecological Issues and the Trades in Live Reef Fishes. In: P.F. Sale (Ed.): Coral Reef Fishes: Dynamics and Diversity in a Complex Ecosystem. San Diego, California, USA: Academic Press. P. 391-420.

Scheibling R. 2013. Oreaster reticulatus. In: J.M. Lawrence(Ed.): Starfish: Biology and Ecology of the Asteroidea. Baltimore, USA: Johns Hopkins University Press. P. 142-152.

Yoshioka P.M., Yoshioka B.B. 1991. A comparison of the survivorship and growth of shallow-water gorgonian species of Puerto Rico. Marine Ecology Progress Series 69(3): 253-260. DOI: 10.3354/meps069253

\title{
ОТЛОВ ИСЧЕЗАЮЩИХ МОРСКИХ БЕСПОЗВОНОЧНЫХ В ПРИОРИТЕТНОМ ДЛЯ СОХРАНЕНИЯ РАЙОНЕ В БРАЗИЛИИ
}

\author{
Ф. К. Ф. Пинхейро ${ }^{1,2}$, Х. Т. Пинхейро ${ }^{1,3,4, *}$, Т. Х. Ф. Коста ${ }^{1}$, \\ Ж. Б. Тейшейра ${ }^{1,5}$, Ж. Л. Гаспарини ${ }^{2}$ Ж.-К. Джойе ${ }^{2}$, А. С. Мартинс ${ }^{2}$ \\ ${ }^{1}$ Экологическая ассочиащия «Голос Природыl», Бразилия \\ ${ }^{2}$ Федеральный университет Эспириту-Санту, Бразилия \\ ${ }^{3}$ Калифорнийский университет в Санта-Крузе, США \\ ${ }^{4}$ Калифорнийская академия наук, США \\ ${ }^{5}$ Калифорнийский университет в Санта-Крузе, Бразилия \\ *e-mail:htpinheiro@gmail.com
}

Отлов морских организмов для аквариумной культуры и декоративно-художественных целей - очень обычен и широко распространен, являясь угрозой для ряда видов, населяющих коралловые рифы. Цель этой работы - сообщить об интенсивном промысле двух видов морских беспозвоночных, морской звезды Oreaster reticulatus и горгонарии Phyllogorgia dilatata, в условиях коралловых рифов в районе, имеющем национальный приоритет для создания морской особо охраняемой природной территории, в штате Эспириту-Санто, на центральном побережье Бразилии. В 2003 г. эти виды были включены в Красный список исчезающих видов Бразилии в качестве находящихся на грани исчезновения, но P. dilatata был исключен из Красного списка в 2014 г., тогда как O. reticulatus и в настоящее время считается уязвимым видом. Но ни один из них не включен в глобальный Красный список МСОП. Случаи отлова этих беспозвоночных были отмечены в 17\% из 51 дня наблюдений (десять экспедиций с марта 2005 г. по февраль 2006 г.). Объем улова составлял до 24 морских звезд и 1000 горгонарий за один день. Морские звезды продавались по 0.50 доллара США каждая, а каждая горгонария за 0.15 доллара США каждая. Для Oreaster reticulatus уже отмечено снижение численности в региональном масштабе, а фактические темпы отлова Phyllogorgia dilatata могут привести к исчезновению местной популяции примерно за 17 лет ее эксплуатации. Ввиду экологической значимости этих двух видов, находящихся под угрозой исчезновения, их отлов создает угрозу всей местной экосистеме каменистых рифов. Необходимо проведение дальнейших экологических и рыбохозяйственных исследований этих видов. А определение и создание морской ООПТ может помочь в управлении всеми неустойчивыми процессами, проводимыми в регионе в настоящее время и ожидаемыми в будущем.

Ключевые слова: Oreaster reticulatus, Phyllogorgia dilatata, горгонария, исчезающие морские беспозвоночные, отлов, морская звезда, морская особо охраняемая природная территория 